\title{
Strategi Komunikasi Pemasaran Online Shop "Youth_Millennial" dalam Meningkatkan Kesadaran Merek dan Penjualan
}

\author{
Alifa Syafna ${ }^{1}$, Anastasia Maria Sri Redjeki ${ }^{2}$ \\ ${ }^{1,2}$ Institut Komunikasi dan Bisnis LSPR, Jakarta, Indonesia
}

\begin{abstract}
ABSTRAK
Dunia fashion tidak pernah berhenti berputar sejak dulu dan terus meningkat hingga kini. Saat ini pasaran produk fashion tetap bergairah, khususnya pada brand clothing line yang memasarkan produknya melalui berbagai platform media sosial yang popular di kalangan generasi muda. Demikian pula yang terjadi pada merek clothing line Youth Millenial yang menyasar kaum muda. Berdasarkan hasil yang diteliti, Strategi Komunikasi Pmeasaran Youth Millenial ditujukan untuk meningkatkan brand awareness dan sales di kalangan anak muda melalui media sosial dengan menggunakan metode SOSTAC (Situation Analysis, Objective, Tactic, Action, Control) dan strategi IMC (Integrated Marketing Communication). Adapun strategi yang digunakan oleh Youth Millenial adalah: bazar, sales promotion, endorsement, kompetisi foto, dan personal selling.
\end{abstract}

Kata kunci: Awareness; Sales; SOSTAC; IMC; Clothing line

\begin{abstract}
The world of fashion has never stopped spinning since then and continues to increase until now. Currently, the market for fashion products remains passionate, especially in clothing line brands that market their products through various social media platforms which are popular among the younger generation. Likewise, what happened to the Youth Millenial clothing line brand which targets young people. Based on the results studied, the Youth Millenial Targeting Communication Strategy is aimed at increasing brand awareness and sales among young people through social media using the SOSTAC (Situation Analysis, Objective, Tactic, Action, Control) method and the IMC (Integrated Marketing Communication) strategy. The strategies used by Youth Millenial are: bazaar, sales promotion, endorsement, photo competition, and personal selling.
\end{abstract}

Keywords: Awareness; Sales; SOSTAC; IMC; Clothing line

\section{PENDAHULUAN}

Media sosial telah menjadi sarana komunikasi yang paling banyak digunakan oleh masyarakat dari berbagai lapisan di seluruh dunia selama beberapa dekade terakhir. Penggunaan sosial media kian meningkat dikarenakan adanya revolusi di dunia teknologi informasi yang mengakibatkan perubahan cepat di berbagai bidang dan mempengaruhi perkembangan zaman. Sosial media, antara lain digunakan orang untuk mencari berbagai informasi apapun yang dibutuhkannya dengan cepat dan mudah. Juga kemudahan komunikasi yang 
disediakannya, termasuk untuk orang-orang yang jaraknya berjauhan, membuat orang beralih menggunakan sosial media sebagai sarana komunikasinya.

Menurut lembaga survey We Are Social, 3,5 milyar bahkan lebih penduduk bumi menggunakan sosial media atau setara dengan 46 persen populasi di dunia. Dalam kurun waktu setahun pertumbuhan penggunaan sosial media akan mencapai lebih dari 250 juta jiwa. Indonesia juga termasuk negara yang sebagian besar masyarakatnya menggunakan sosial media (Pertiwi, 2019). Menurut penelitian yang dilakukan We Are Social, perusahaan media Inggris yang bekerjasama dengan Hootsuite, masyarakat Indonesia termasuk aktif dalam menggunakan sosial media. Sebanyak 160 juta penduduk dari total 272,1 juta penduduk Indonesia adalah pengguna aktif akun sosial media (We are social, 2020).

Kegiatan di media sosial yang didukung oleh pertumbuhan industri e-commerce di Indonesia menyebabkan terjadinya peningkatan jumlah transaksi jual beli melalui media sosial. Salah satu media sosial yang menawarkan kode diskon untuk situs belanja online di Indonesia yang bernama CupoNation, telah memprediksi bahwa tingkat jumlah pembeli online ini akan terus meningkat. Olivia Putri, Public Relations and Communications Manager CupoNation menyebutkan, bahwa tahun 2016 lalu jumlah pembeli online yang ada di Indonesia telah mencapai 9,6\% dari jumlah populasi keseluruhan dan semakin meningkat pada tahun 2017 sebanyak $10,7 \%$. Pertumbuhan ini didukung pendapatan pasar e-commerce yang ada di Indonesia, yaitu sebesar 6,1 miliar dollar AS (2016), meningkat jadi 7,5 milliar AS (2017) dan diprediksi semakin meningkat menjadi 9,1 milliar dollar AS di tahun 2018 (Putera, 2018).

Data di atas memperlihatkan adanya peluang besar bagi masyarakat Indonesia untuk membangun usaha startup bisnis. Startup merupakan kata serapan yang diambil dari Bahasa Inggris yang memiliki makna dasar yaitu memulai atau merintis. Ries dalam bukunya yang berjudul The Lean Startup: Ketika Inovasi Tanpa Henti Menciptakan Kesuksesan Bisnis Secara Radikal mengatakan, "Startup adalah sebuah institusi, bukan sekadar produk sehingga membutuhkan manajemen jenis baru yang secara khusus dirancang untuk menghadapi kepastian yang ekstrem." (Ries, 2018, para.1). Dari pengertian tersebut dapat disimpulkan bahwa startup adalah ide bisnis baru yang berbeda dari model bisnis sebelumnya, sehingga para pebisnis harus siap menerima dan melakukan perubahan yang terjadi pada saat ini.

Berdasarkan data Badan Pusat Statistik (BPS), produksi industri pakaian pada 3 bulan pertama tahun 2019 tumbuh sebesar 29,19\% secara tahunan. Sementara secara quarter-to-quarter sektor ini tumbuh sebesar 8,79\%, yaitu kedua tertinggi setelah industri furniture. Ernovian G. Ismy, Sekretaris Jenderal Asosiasi Pertekstilan Indonesia (API), mengkonfirmasi tentang pertumbuhan produksi pada kuartal I/2019 ini dan terjadi permintaan produk pakaian jadi yang terus meningkat (Rini, 2019). 
Pesatnya peluang bisnis di industri fashion di Indonesia memunculkan ide-ide kreatif dengan konsep-konsep yang menarik. Salah satu konsep bisnis fashion yang menarik adalah clothing line. Clothing Line merupakan salah satu bisnis fashion yang mampu menarik perhatian generasi milenial. Istilah clothing line diartikan sebagai sebuah usaha yang memproduksi desain dan produk fesyen (Syahid,2018).

Pada tahun 2018, Pekan Raya Indonesia (PRI) menghadirkan sesuatu yang baru, yaitu mengadakan Clothfest yang menampilkan 80 merek lokal. Clothfest merupakan pameran dan bazaar produk lokal seperti clothing distro, fashion, merchandise, dan lainnya (Anna, 2018). Industri clothing line ini juga didukung oleh adanya kesadaran masyarakat Indonesia untuk membeli produk lokal, bahkan kini para clothing line lokal diminati oleh pasar global. Hal ini karena adanya kreativitas dan kerja keras yang dilakukan oleh para pemiliki brand clothing line lokal. Brand dengan label lokal ini juga difasilitasi oleh BEKRAF (Badan Ekonomi Kreatif) yang terus mendorong agar label lokal mendapat ruang di berbagai macam e-commerce. Didukung juga oleh banyaknya event yang khusus menonjolkan merek-merek lokal seperti Brightspot. Event semacam ini diadakan untuk membangun komunitas para brand lokal agar bisa mempresentasikan brand lokal tersebut ke media (Bekraf, 2018).

Youth Millennial merupakan brand clothing line baru yang dimiliki oleh Alifian Setiawan Tahir dan Iswandi Irham Tahir, berdiri pada awal tahun 2019. Youth Millennial memproduksi beberapa jenis pakaian yang pemasarannya ditujukan terutama bagi kaum muda atau generasi Milennial. Produk kaus yang diproduksi oleh Youth Millennial menggunakan bahan kaus premium cotton short sleeve 7200 yang memiliki tekstur yang lembut dan nyaman digunakan. Material bahan kausnya tidak panas dan jahitan yang dihasilkan tidak terlihat, contohnya model Hoodie yang menggunakan bahan cotton fleece (A.S. Tahir, Komunikasi Pribadi, Oktober 31,2019). "Material untuk produk kemeja yang digunakan pada Youth Millennial adalah bahan katun yang sangat nyaman dan sejuk dipakai untuk berkegiatan sehari-hari, karena katun memiliki daya serap yang baik sehingga sangat cocok digunakan di negara tropis seperti Indonesia." (A.S. Tahir, wawancara pra-reset, Oktober 31, 2019).

Penulis akan membuat perencanaan strategi komunikasi pemasaran dengan tujuan meningkatkan brand awareness dan sales untuk clothing line online shop "youth_millennial". Merek Youth Millennial terbilang baru di dunia bisnis online shop, ini membuat brand Youth Millennial belum dikenal di Indonesia. Faktor ketidaksadaran masyarakat pada brand Youth Millennial otomatis juga berdampak pada sales dari brand ini. Menurut hasil survey terhadap 100 orang mengenai brand awareness online shop Youth Millennial, 19\% pernah mendengar brand Youth Millennial dan 81\% tidak mengetahuinya (Data Olahan Perancang Karya, 2019). Untuk itu, pembuat karya ingin membuat strategi marketing komunikasi guna meningkatkan brand awareness dan sales dari brand Youth Millennial. 
Salah satu kompetitor Youth Millennial adalah Eitmiles yang berdiri sejak pertengahan 2019. Desain dan produk baju kaus dan hoodie Eitmiles memiliki kesamaan dengan konsep desain dan produk YouthMillennial. Begitupun dari sisi harga, perbandingan harga keduanya tidak berbeda jauh (Data Olahan Perancang Karya, 2019). Kompetitor lain yang berdiri lebih awal sejak 2016 adalah Crack Apparrel Official yang menjual berbagai macam kaus, hoodie, sweater hingga topi. Desain kaus dan hoodie pada Crack Apparel Official ini cukup beragam dengan harga yang tidak jauh beda dengan Youth Millennial (Data Olahan Perancang Karya, 2019).

Kelebihan Youth Millennial atau unique selling point adalah desainnya yang bergaya pop, kualitas produk yang baik dan harga yang terjangkau. Melalui perencanaan komunikasi pemasaran yang baik, merek ini akan mampu bersaing menghadapi para kompetitornya.

Berdasarkan penjelasan pada latar belakang penelitian sebagaimana dipaparkan di atas, maka rumusan masalah dan juga tujuan perencanaan ini adalah :

1. Bagaimana membuat perencanaan strategi komunikasi pemasaran untuk meningkatkan brand awareness dan sales pada brand clothing line Youth Millennial?

2. Tujuan pembuatan perencanaan ini untuk meningkatkan brand awareness dan sales pada bisnis online shop clothing line Youth Millennial.

\section{METODOLOGI PELAKSANAAN}

\section{SOSTAC}

Dalam perencanaan strategi komunikasi pemasaran Youth Millennial, pembuat karya akan menggunakan langkah-langkah SOSTAC, yaitu Situation Analysis, Objectives, Strategy, Tactics, Action, dan Control, menurut Smith dan Zook (2011, p.266) pada bukunya yang berjudul Marketing Communications: Offline and Online Integration, Engagement, and Analystics.

\section{Situation Analysis (Where are we now?)}

Analisis situasi mempunyai tujuan untuk dapat mengetahui apa saja yang sedang terjadi pada pasar saat ini agar bisa mengikuti perkembangan zaman yang ada. Analisis situasi fokus terhadap hal-hal yang akan berpengaruh pada strategi komunikasi pemasaran yang akan dilakukan. Analisis situasi terbagi menjadi dua yaitu analisis eksternal dan analisis internal. Pada analisis internal hal yang dilakukan adalah menganalisis semua yang terlibat dalam proses memperjualbelikan barang ke pasaran.

Selain itu analisis internal harus dapat mengetahui apa saja kelemahan dan kelebihan yang dimiliki perusahaan. Sedangkan, untuk analisis eksternal hal yang dilakukan adalah mengetahui hal-hal tentang suatu perusahaan dalam menciptakan citra dalam suatu produknya. Karakteristik pelanggan, pola belanja, proses pengambilan keputusan untuk 
membeli sesuatu adalah salahsatu hal penting untuk dicermati dalam analisis eksternal (Prasetyo et al., 2018, p.73).

Analisis SWOT adalah salah satu analisis yang digunakan untuk merencanakan perencanaan strategi. Analisis SWOT terbagi menjadi dua yaitu: faktor internal dan eksternal. Faktor Internal terdiri dari Strength (Kekuatan) dan Weakness (Kelemahan) yang ada dalam perusahaan dan faktor eksternal terbagi menjadi Opportunities (Peluang) dan Threat (Ancaman) yang didasarkan pada lingkungan di luar perusahaan (Primyastanto, 2016).

1. Strength (Kekuatan) merupakan keadaan dan kesanggupan internal yang sifatnya positif dan memungkinkan suatu perusahaan mendapatkan keberhasilan dalam mencapai visi dan misi dalam perusahaan.

2. Weakness (Kelemahan) merupakan kekurangan yang dimiliki suatu perusahaan yang bisa menyebabkan kegagalan dalam meraih visi dan misi dalam suatu perusahaan.

3. Opportunities (Peluang) merupakan faktor yang ada di luar organisasi yang sifatnya positif dan dapat menguntungkan perusahaan serta dapat membantu dalam mencapai visi dan misi perusahaan.

4. Threat (Ancaman) merupakan faktor yang ada di luar organisasi yang sifatnya negatif dan dapat mengagalkan perusahaan dalam mencapai visi dan misi (Mahi \& Trigunarso, 2017, p.66).

\section{Objectives (Where do we want to go?)}

Para pembuat karya akan menggunakan tuntunan SMART untuk membuat tujuan strategi komunikasi pemasaran Youth millennial. Menurut Dietmar Sokowski "objectives must be SMART (Specific, Measurable, Achievable, Realistic, Time) where each letter in SMART is the first letter of an adjective that describes a property that objectives must possess if they are to be good and useful objectives". Tujuan haruslah bersifat SMART (Specific, Measurable, Achievable, Realistic, Time) jika ingin menjadi tujuan yang baik dan berguna (Sokowski, 2015).

\section{Strategy (How do we get there?)}

Strategi yang akan diterapkan oleh Youth Millennial dalam meningkatkan brand awareness dan sales yaitu STP (Segments, Target Market, Positioning). Segmenting atau segmentasi merupakan hal yang sangat penting dalam kegiatan pemasaran. Menurut buku Periklanan Komunikasi Pemasaran Terpadu (Morrisan, 2010), segmentasi pasar merupakan suatu aktivitas untuk mengelompokkan pelanggan ke dalam kotak-kotak yang memiliki macam, sifat, watak yang sama. Khalayak pelanggan umum memiliki beranekaragam sifat, perusahaan akan sulit dalam melayani pelanggannya jika belum tersegmentasi. Maka dari itu, jika ingin menguasai pasar, perusahaan harus benar-benar mengerti konsep segmentasi. Ada beberapa segmentansi yang harus dipelajari oleh perusahaan, yaitu: 
1. Segmentasi Demografis

Dalam segmentasi demografis ini pembagian pasar dikelompokkan berdasarkan usia, jenis kelamin, pekerjaan, pendidikan, pendapatan, agama, suku dan kebangsaan.

2. Segmentasi Geografis

Segmentasi geografis ini mengelompokkan khalayak pelanggan berdasarkan jangkauan geografisnya seperti negara, provinsi, kabupaten,kota, sampai ke lingkungan perumahan.

3. Segmentasi Geodemografis

Segmentasi geodemografis ini adalah segmentasi campuran antara segmentasi demografis dan segmentasi geografis. Dalam segmen ini, pengelompokkan geografis harus sesempit mungkin. Dan dalam segmentasi geodemografis ini dikatakan bahwa seseorang yang tinggal di daerah geografis yang sama akan memiliki karakter demografis yang sama pula.

4. Segmentasi Psikografis

Segmentasi psikografis mengelompokkan khalayak pelanggan berdasarkan gaya hidup dan kepribadian manusia.

Targeting adalah upaya mengetahui segmen-segmen pasar yang telah ditetapkan sesuai dengan kriteria-kriteria pelanggan tertentu dan supaya dapat mengkomunikasikan nilai ke target yang tepat. Dengan diadakannya targeting yang benar dapat memberi kemudahan pada perusahaan untuk memasarkan produknya (Kembuan, Mananeke \& Soegoto, 2014, p.854). Menurut Kotler (2003:235) dalam Kembuan et all (2014) targeting adalah tindakan untuk mengevaluasi minat setiap kelompok pasar dan memilih sebagian kelompok pasar tersebut untuk dipilih sebagai target.

Dalam buku Marketing Plan! ditegaskan bahwa targeting adalah suatu proses dalam menilai dan menentukkan satu atau lebih segmen pasar yang akan dipilih. Tujuan dari targeting sendiri adalah untuk memberi kemudahan dalam menjangkau segmen yang ingin diraih serta memberikan pelanggan kepuasan yang lebih (Wijayanti, 2017).

Positioning merupakan sebuah strategi penempatan produk yang ingin dipasarkan ke dalam benak konsumen, positioning tidak dilakukan kepada produk namun bagaimana menanamkan brand image di dalam benak konsumen. Pemasar harus membuat positioning yang unik dibanding produk lain agar konsumen selalu mengingat produk yang ingin dipasarkan tersebut (Rangkuti, 2011).

Positioning sangat penting dilakukan oleh sebuah perusahaan jika ingi memasarkan produk atau jasa, karena positioning dapat menjadi kunci agar tidak mudah tergusur oleh competitor dan juga positioning dapat menjadi pembeda suatu produk dari produk lainnya (Firmanzah, 2011, p.68). 


\section{Tactics (The details of the strategy)}

Taktik adalah langkah-langkah yang diambil untuk melaksanakan sebuah Strategi, jika strategi dan tujuan pemasaran telah ditentukan maka otomatis harus membuat taktik apa yang efektif untuk mendukung strategi tersebut (Supriatna, Adiyanto, dan Sunaryo, 2019, p.26).

\section{Action (Putting the plan to work)}

Menurut Dave Chaffey, P.R Smith, dan Paul Rusell "Action is the detailed working out of tactics" (Chaffey dan Smith, 2013, p.538). Aksi adalah sebuah rincian dari taktik atau langkahlangkah yang dilakukan untuk merealisasikan taktik yang telah dibuat untuk mencapai tujuan yang diinginkan.

\section{Control (Monitoring, reviewing, modifying)}

Kontrol bisa dilakukan dengan cara melakukan monitoring dan review. Menurut Dave Chaffey dan P.R Smith "Build in a review process to your plans based on web analystics and management dashboards" (Chaffey \& Smith, 2017, p.556). Setelah melaksanakan actions, perusahaan harus melakukan monitoring review yang telah diberikan oleh konsumen pada strategi komunikasi pemasaran yang telah dilaksanakan.

\section{Budgeting}

Selain langkah-langkah SOSTAC di atas, perancang karya juga membuat perencanaan biaya atau budgeting. Tujuan budgeting untuk mendapatkan sebuah kentungan dari perusahaan, (Anwar, 2019, p.126).

\section{Keterbatasan Karya}

Perencanaan karya yang dibuat telah dilakukan secara maksimal, namun terdapat keterbatasan yang dimiliki oleh karya tersebut, yaitu bagaimana strategi perencanaan karya ini dapat diterima di pasarnya. Kebutuhan pasar tidak selalu sama dan akan selalu berubahubah, hal ini dapat memunculkan tantangan bagaimana membuat sebuah karya yang berbeda dari para pemasar lain, sehingga karya tersebut dapat diterima khalayak. Keterbatasan lainnya adalah bahwa perencanaan ini belum sampai ke tahap implementasi. Diharapkan pemilik Youth Millenial akan melaksanakan perencanaan karya ini, sehingga dapat membantu meningkatkan brand awareness dan sales pada produknya.

\section{HASIL DAN PEMBAHASAN / RESULT AND ANALYSIS}

\section{Profil Perusahaan}

Youth Millennial adalah sebuah bisnis clothing line yang didirikan oleh Alifian Setiawan Tahir dan Iswandi Irham Tahir pada awal tahun 2019, bergerak dalam industri Fashion yang menjual berbagai jenis pakaian berupa kemeja, hoodie, dan kaus. Pakaian yang dijual di Youth Millennial bisa digunakan oleh perempuan dan laki-laki karena desainnya yang netral. Desain 
dari produk Youth Millennial ini memiliki gaya casual yang simpel dan cocok untuk digunakan sehari-hari. Material bahan yang digunakan untuk produksi kaus adalah premium cotton shortsleeve 7200 dan material kemeja menggunakan bahan katun. Kisaran harga produk Youth Millennial mulai dari Rp 125.000,00 sampai dengan Rp 275.000,00. Total produk yang terjual sejak awal Januari tahun 2019 sampai April 2020 sebanyak 710 potong. Semua produk Youth Millennial dipasarkan secara online melalui media sosial Instagram. Sampai tanggal 3 Juni 2020 Youth Millennial tercatat memiliki 5.556 followers (Data Olahan Perancang Karya, 2020).

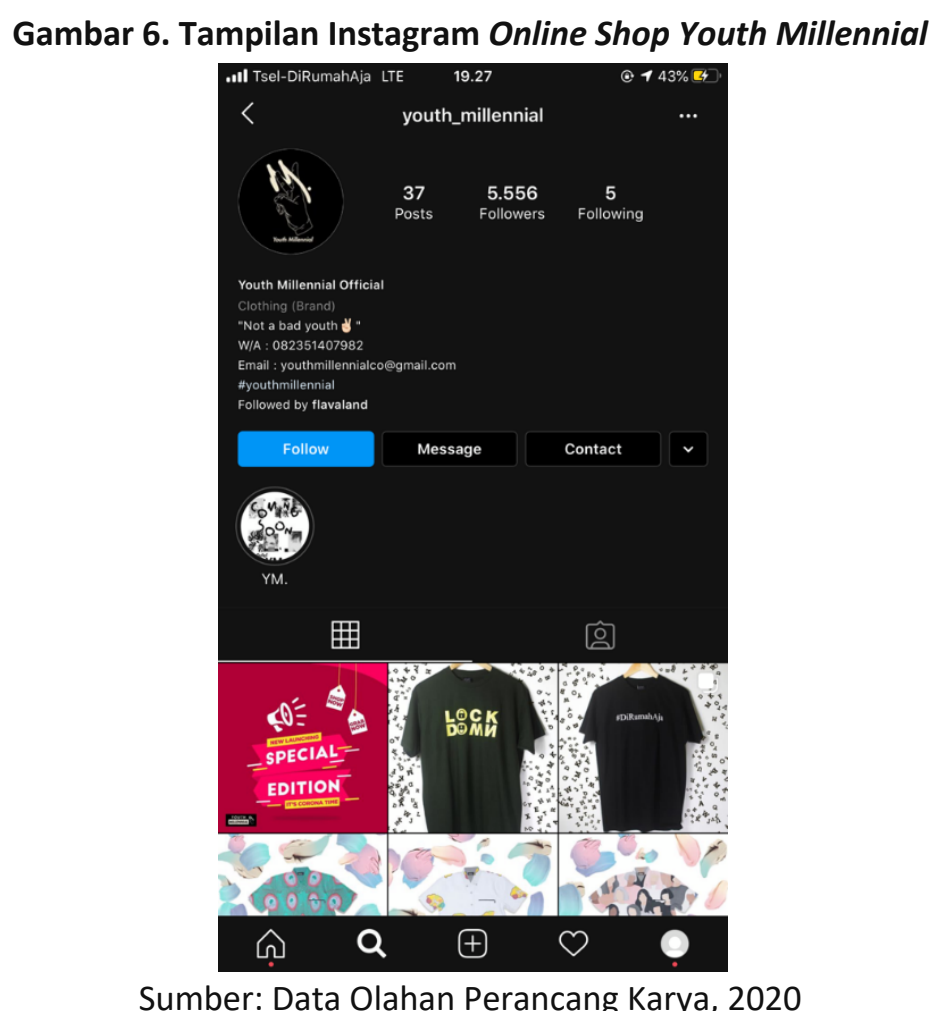

\section{Brand Element}

\section{Nama}

Nama Youth Millennial diambil dari Bahasa Inggris, "Youth" berarti anak muda dan "Millennial" merujuk pada generasi millennial yang lahir mulai tahun 1980 sampai tahun 2000. Youth Millennial memiliki makna orang muda dari generasi milenial, sekaligus menegaskan fokus gaya disain dan target market yang dituju adalah para pemuda milenial masa kini. 


\section{Gambar 7. Brand Youth Millennial}

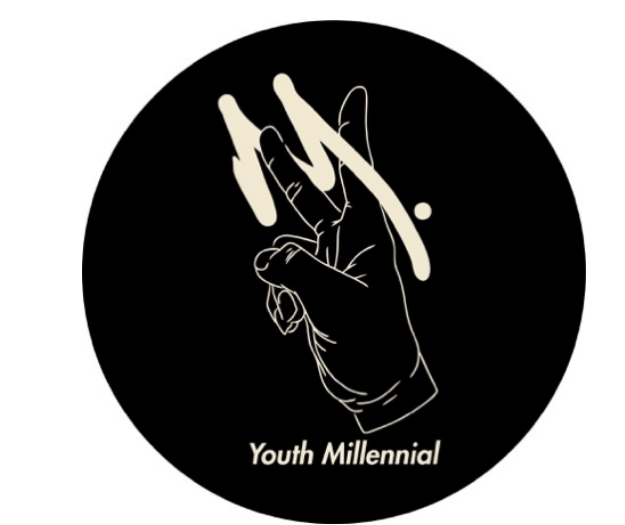

Sumber: Data Olahan Perancang Karya, 2020

\section{Slogan "Not a Bad Youth"}

Slogan Youth Millennial adalah "Not a Bad Youth" dalam bahasa Indonesia artinya "Bukan Anak Muda Buruk". Pesan yang ingin disampaikan di balik kalimat tersebut adalah dengan memilih dan menggunakan produk clothing line Youth Millennial saya bukan anak muda yang buruk, sebaliknya menegaskan bahwa saya mewakili sosok anak muda dengan gambaran diri yang baik, pergaulan yang baik, dan peduli terhadap lingkungan sekitar.

\section{Visi Misi}

Visi:

Bertekad untuk menjadi perusahaan brand clothing line yang memiliki harga terjangkau dan pelayanan yang baik serta mampu bersaing di pasaran.

Misi:

- Selalu memproduksi desain pakaian yang up to date.

- Berusaha memenuhi kebutuhan dan keinginan para pelanggan.

- Selalu mengedepankan kerjasama yang baik agar bisnis yang dijalankan bisa semakin berkembang.

\section{Packaging}

Kemasan produk Youth Millennial berbentuk amplop berwarna cokelat, ukuran $30 \times 22 \mathrm{~cm}$ (seukuran kertas A4) disertai logo Youth Millennial di pojok kanan atas, disertai label dan hang tag. 


\section{Gambar 8. Packaging Brand Youth Millennial}

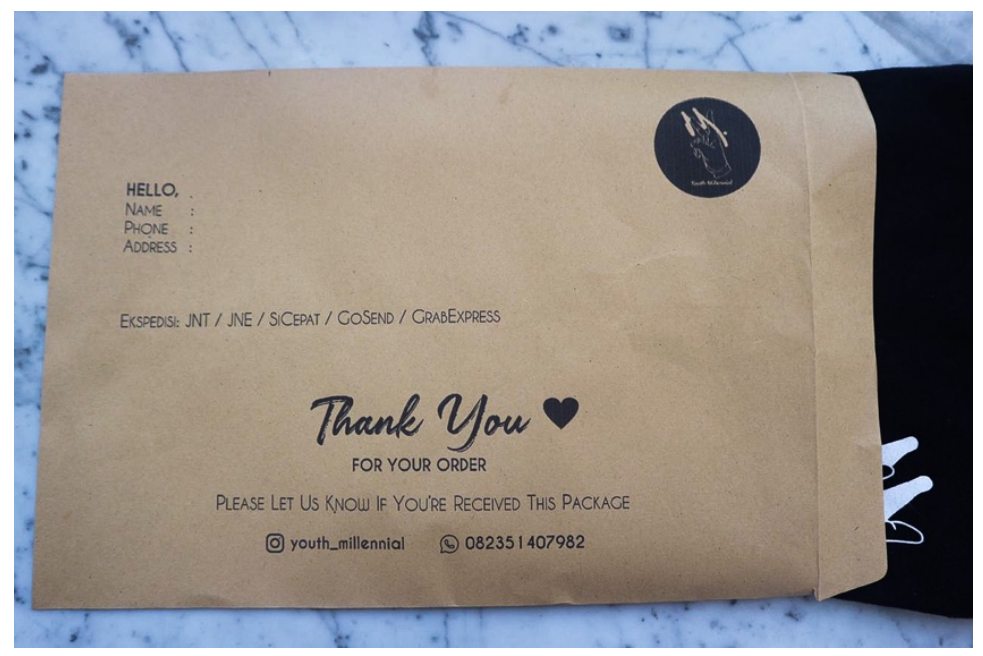

Sumber: Data Olahan Perancang Karya, 2020

\section{Gambar 9.. Hang Tag Baju Brand Youth Millennial}

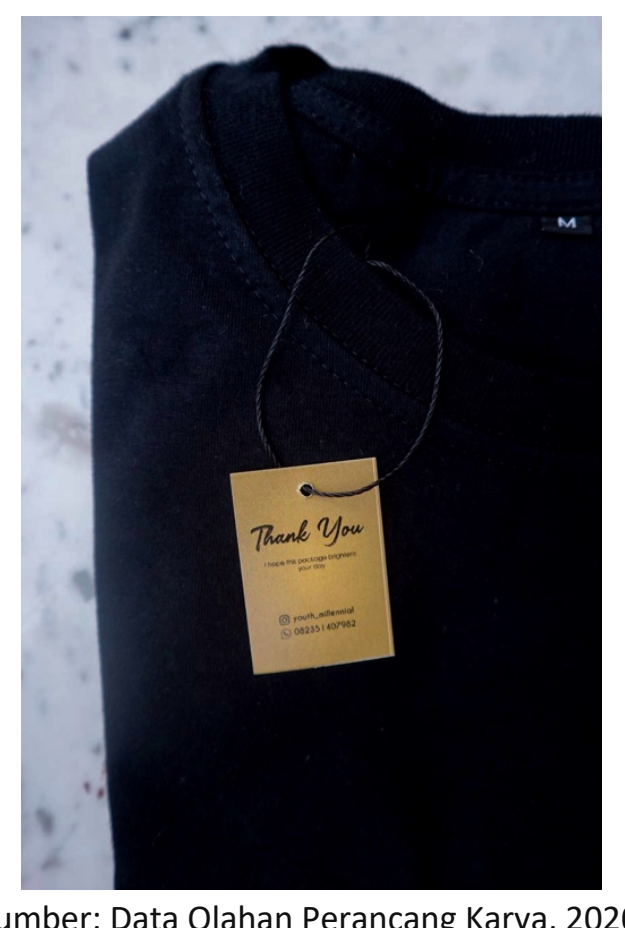

\section{Analisa Kompetitor}

Kompetitor langsung produk Youth Millennial adalah Eitmiles dan Crack Apparrel Official Ketiga merek ini menawarkan produk untuk target pemasaran yang sama dengan desain sejenis dan kisaran harga yang tidak jauh berbeda.. 
Tabel 2. Analisa online shop clothing line Eitmiles

\begin{tabular}{ll}
\hline Informasi & Keterangan \\
\hline Produk & $\begin{array}{l}\text { Produk yang dipasarkan berupa kaus, hoodie, tas, } \\
\text { dan topi }\end{array}$ \\
\hline Harga & Rp. 129.000 - Rp.149.000 \\
\hline Lokasi & Online \\
\hline Positioning & Memproduksi produk fashion yang dapat \\
& membentuk keinginan pasar \\
\hline Target Market & 15 tahun - 25 tahun \\
\hline Strengthness & -Memiliki design yang sesuai dengan keinginan \\
& pelanggan \\
& - Selalu memproduksi design yang uptodate \\
& - Selalu mengedepankan strategi Komunikasi \\
& pemasaran yang unik untuk meningkatkan \\
& awareness \\
\hline Weakness & - Warna baju yang diproduksi tidak bervariasi \\
& -Harga yang cukup mahal \\
\hline
\end{tabular}

Tabel 3. Analisa online shop clothing line Crack Apparel Official

\begin{tabular}{ll}
\hline Informasi & Keterangan \\
\hline Produk & $\begin{array}{l}\text { Produk yang dipasarkan berupa kaus, hoodie, } \\
\text { sweater dan topi }\end{array}$ \\
\hline Harga & Rp. $65.000-$ Rp. 279.000 \\
\hline Lokasi & Online \\
\hline Positioning & Clothing line anak muda yang tinggal di wilayah \\
& sub urban \\
\hline Target Market & $\mathbf{1 6}$ tahun - 30 tahun \\
\hline Strengthness & -Harga cukup terjangkau \\
& -Memiliki design yang unik \\
& -Packaging yang berbeda, dengan konsep seperti \\
& box mainan \\
\hline Weakness & -Produksi belum dalam kuantitas yang banyak \\
& -Pemasarannya masih lemah \\
\hline
\end{tabular}

Sumber: Data Olahan Perancang Karya, 2020

\section{Situation Analysis}

Guna melakukan Analisa situasi merek Youth Millennial, para pembuat karya memilih menggunakan analisis SWOT yang terdiri dari :

\section{a. Strength}

1. Youth Millennial merupakan fashion brand yang melakukan pemasaran melalui media sosial yaitu platform Instagram dengan nama akun @youth_millennial dengan jumlah 5.556 followers.

2. Harga terjangkau berkisar $\mathrm{Rp} 125.000,00$ sampai $\mathrm{Rp} 275.0000,00$.

3. Memiliki kualitas bahan yang bagus.

4. Membuat design yang selalu up to date. 
5. Selain fokus dalam bisnis juga peduli dengan lingkungan sosial sejak awal sejak

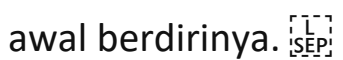

6. Pada situasi pandemi covid19 ini tidak harus melakukan transformasi bisnis offline ke online.

7. Situasi pandemi covid19 tetap bisa bertahan karena bisnisnya dijalankan melalui online sejak awal.

b. Weakness

1. Brand awareness masih rendah, konsumen masih belum sadar tentang keberadaan merek Youth Millennial.

2. Tingkat penjualannya masih harus ditingkatkan.

3. Tidak memiliki toko offline, menyulitkan pelanggan yang ingin berbelanja langsung.

4. Kurang gencar melakukan promosi untuk menarik perhatian konsumen.

5. Belum memiliki model untuk foto pada katalog produk.

6. Belum memiliki tukang jahit sendiri sehingga bergantung pada tukang jahit di luar yang tidak bisa kerja fulltime.

c. Opportunities

1. Dengan adanya situasi pandemi ini, masyarakat dihimbau untuk tetap di rumah sehingga berdampak pada aktivitas belanja online yang terus meningkat.

2. Dunia fashion semakin bergairah dengan dukungan berbagai pihak termasuk pemerintah yang memberikan perhatian bagi pelaku ekonomi kreatif.

d. Threats

1. Konsumen setia pada merek yang selama ini sudah digunakan dan sulit dialihkan.

2. Banyak merek clothing line sejenis yang memasarkan produknya di media sosial.

3. Perkembangan teknologi informasi di bidang e-commerce yang pesat membuat konsumen lebih mudah mencari produk yang dibutuhkan dan lebih cermat melakukan pembelian.

4. Harga bahan baku yang tidak stabil dan terus meningkat mengakibatkan kenaikan harga pada produk Youth Millennial.

5. Krisis ekonomi global akibat pandemi covid-19 berdampak pada minat dan daya beli konsumen.

\section{Objectives}

Dalam membuat objective atau tujuan para pembuat karya memilih untuk menggunakan metode SMART (Specific, Measurable, Achievable, Relevant, Tinme), yaitu: 


\section{Specific}

Meningkatkan brand awareness dari 19\% menjadi 50\% dan menaikan sales dari terjual 710 buah meningkat 40\% menjadi 994 buah produk terjual, melalui pelaksanaan action dari strategi perencanaan yang dibuat dengan cer- mat dan kreatif untuk jangka waktu kegiatan selama satu tahun.

\section{Measureable}

Pengukuran dilakukan berdasarkan meningkatnya jumlah followers (5.556 followers) dan total penjualan produk selama kurun waktu satu tahun.

\section{Achiveable}

Menyusun perencanaan program yang kreatif dan dapat dilaksanakan dengan baik sesuai dengan tujuan yang ingin dicapai. Perencanaan disesuaikan dengan situasi dan kondisi baik internal maupun eksternal sehingga dapat berhasil jika dilaksanakan dengan baik.

\section{Relevant}

a. Perencanaan Strategi Komunikasi Pemasaran dilakukan pada platform sosial media yaitu Instagram.

b. Membuat perencanaan pemasangan iklan pada platform sosial media yaitu Instagram untuk menjangkau target market yang lebih luas.

c. Membuat perencanaan untuk mengikuti kegiataan offline event sebagai ajang temu muka langsung dengan konsumen, seperti bazaar di mal - mal, sekaligus sebagai ajang untuk meningkatkan sales.

d. Membuat perencanaan kampanye sosial sebagai bentuk kepedulian perusahaan terhadap lingkungan sosial sekaligus untuk meningkatkan brand awareness.

e. Merencanakan akses penjualan produk yang lebih luas dengan menggunakan platform e-commerce seperti Shopee dan Tokopedia.

Time

Merencanakan jangka waktu yang akan digunakan Youth Millennial dalam melakukan strategi komunikasi pemasaran ini adalah selama 12 bulan.

\section{Strategy}

Pada tahapan Strategy, para pembuat karya akan menggunakan strategi STP (Segments, Targeting, Positioning) agar sesuai dengan jenis dan tujuan produk yang ingin dipasarkan.

\section{Segments}

Langkah ini diperlukan agar perencanaan yang dibuat bisa semakin segmentif yang terdiri dari 3 segmen yaitu geographic, demographic dan psychographic:

\section{Segmentasi Geographic}


Segmentasi geografis produk Youth Millennial adalah masyarakat JABODETABEK (Jakarta, Bogor, Depok, Tanggerang, Bekasi).

2. Segmentasi Demographic

Usia: 18 sampai 30 tahun.

Jenis Kelamin: pria dan wanita.

Pendidikan: SMA, S1, dan S2.

Pekerjaan: karyawan, entrepreneur, pebisnis muda.

Agama: semua

3. Segmentasi Psychographic

Social Grade: A, B, dan C.

Gaya Hidup: orang yang aktif menggunakan sosial media dan orang yang menyukai fashion.

\section{Targeting}

Produk Youth Millennial ditargetkan bagi laki-laki dan perempuan muda yang berdomisili JABODETABEK pada semua golongan social grade yang berprofesi sebagai pelajar, mahasiswa, karyawan muda sampai pebisnis muda dengan usia antara 18 sampai dengan 30 tahun.

\section{Positioning}

Merek Youth Millennial memposisikan diri sebagai:

a. Brand clothing line yang memiliki kepedulian dengan lingkungan sosial.

b. Youth millennial memiliki tag line "Not a bad Youth" yang berarti Youth Millennial merupakan brand yang dirancang untuk menciptakan efek positif di kalangan anak muda.

STP merupakan pedoman bagi pembuat karya dalam merencanakan langkah selanjutnya agar lebih tepat sasaran.

\section{Strategi Komunikasi Pemasaran}

Sebagai mrek pendatang baru, Youth Millennial harus melaksanakan program komunikasi pemasaran yang tepat agar dapat meningkatkan kesadaran merek di kalangan publik yang sekaligus meningkatkan sisi bisnisnya, yaitu angka penjualan. Strategi yang akan dibuat dalam perencanaan ini menggunakan Integrated Marketing Communication atau Komunikasi Pemasaran Terpadu, yaitu menggabungkan beberapa cara dalam satu keutuhan dalam menyampaikan pesan kepada publik melalui sarana media sosal, yaitu:

1. Increase Brand Awareness

Merencanakan kegiatan di bidang kampanye sosial dalm bentuk kompetisi foto melalui platform Instagram. Ada 3 kegiatan kampanye sosial ini: Pertama berjudul "\#Covidoctive", yaitu sebuah photo competition yang mengajak publik menceritakan kegiatan apa saja yang dilakukan selama masa pendemi. Kedua 
berjudul "Show Yourself" yang fokus mengajak publik agar selalu percaya diri dengan segala kekurangan yang mereka miliki. Ketiga berjudul "PungutUntukBumi" yang mengajak publik lebih sadar akan kebersihan bumi.

2. Increase Sales

Merencanakan kegiatan promosi yang akan memberikan keuntungan bagi pelanggan agar tertarik pada produk yang ditawarkan:

- Birthday Gifts

Memberikan potongan harga sebesar umur pelanggan yang berulang tahun dengan menunjukan bukti KTP.

- Buy 3 Get 1

Setiap pembelian 3 buah produk akan mendapat 1 free produk Youth Millennial.

- Year End Treat

Potongan pembelian sebesar $10 \%$ setiap akhir tahun.

- Idul Fitri Treat

Discount sebesar $10 \%$ setiap hari raya idul fitri.

- Valentine Special

Potongan harga sebesar $14 \%$ untuk pembelian kedua

- Discount ongkir 10k

Potongan ongkos kirim sebesar Rp. 10.000,- bagi semua transaksi

3. Celebrity Endorsement

Memanfaatkan celebrity endorsement yaitu memilih beberapa selebriti sebagai influencer yang berpengaruh untuk mempromosikan produk Youth Millennial.

4. E-commerce

Merencanakan perluasan pemasaran produk melalui kerjasama dengan Shopee dan Tokopedia untuk menjangkau pelanggan yang lebih besar dan memudahkan pelanggan membeli produk Youth Millennial.

5. Instagram ads

Merencanakan penempatan iklan pada platform Instagram untuk menyebarluaskan informasi ke target audience yang lebih luas.

6. Personal Selling

Merencanakan kegiatan offline pada saat situasi sudah memungkinkan agar dapat bertemu langsung dengan publik pelanggan, yaitu dengan mengikuti bazaar di mal tertentu.

\section{Tactics}

Perencanaan Taktik dibuat untuk mendukung terlaksananya Strategi yang telah dibuat. 
Kampanye Sosial Kompetisi Foto ini dilakukan di platform Instagram untuk meningkatkan brand awareness Youth Millennial, yang direncanakan akan dilaksanakan sebanyak 3 kali dalam setahun, yaitu:

1. Social Campaign: Photo Competition “\#Coviductive" (16-30 Agustus 2020)

Kondisi pendemi mengharuskan banyak orang melakukan kegiatan di dalam rumah disbanding di luar rumah. Youth Millennial akan mengajak audiences berpartisipasi dalam photo competition. Para peserta photo competition ini wajib mengikuti akun Instagram Youth Millennial dan membeli serta memakai produk special edition: it's corona time lalu mengunggah foto aktifitas mereka selama di rumah saja. Membuat caption dengan hastagh \#ItsCoronaTime \#CoviductiveYM semenarik mungkin. Wajib tag akun Instagram @youth_millennial. Kampanye ini akan diselenggarakan pada tanggal 16 Agustus sampai 30 Agustus 2021. Pemenang akan diumumkan pada tanggal 31 Agustus pada akun Instagram Youth Millennial. Bagi peserta yang memiliki foto dan caption yang unik maka akan mendapatkan hadiah berupa uang tunai, juara 1 ebesar 3 juta rupiah, juara 2 sebesar 1,5 juta rupiah, dan juara 3 sebesar 750 ribu rupiah. Hadiah untuk pemenang akan di transfer langsung ke rekening para pemenang.

\section{Gambar 10. \#Coviductive Photo competition}

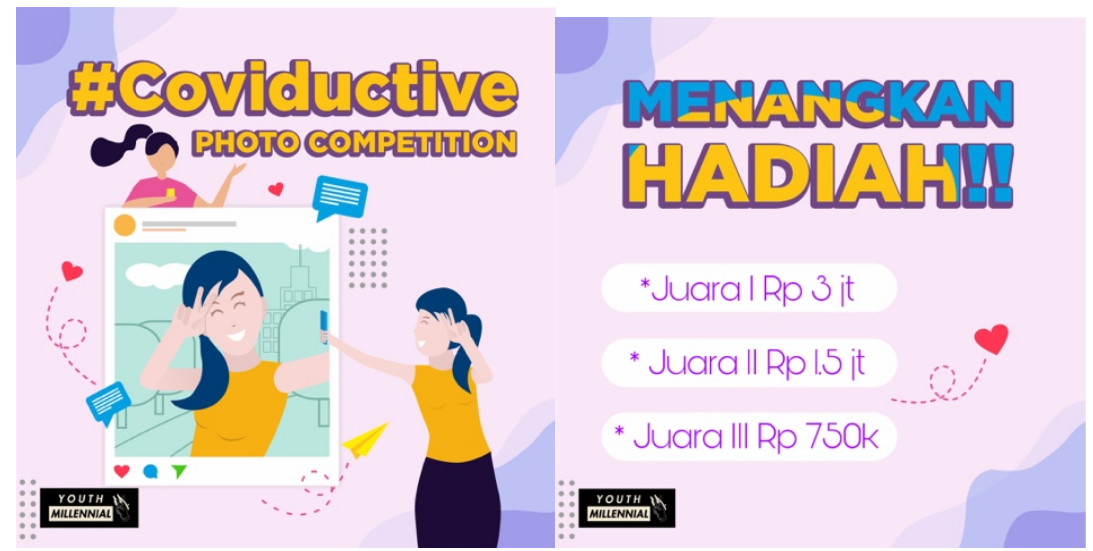

Sumber: Data Olahan Perancang Karya, 2020

2. Social Campaign: Photo Competition "Show YourSelf" (17-30 Januari 2021)

Tujuan kampanye ini mengajak publik menunjukan rasa percaya diri dan menghilangkan rasa insecure pada diri mereka. Para peserta photo competition ini wajib memposting foto dengan menampilkan kekurangan yang mereka miliki dan menunjukan rasa percaya diri dengan menggunakan produk baju Youth Millennial, serta membuat caption dengan hashtag \#ShowYourSelfYM \#YouthMillennial seunik mungkin tentang pentingnya percaya diri. Peserta wajib tag akun Instagram @Youth_Millennial. Campaign ini akan diselenggarakan pada tanggal 17 Januari sampai tanggal 30 Januari dan pemenang akan diumumkan pada tanggal 31 Januari. Bagi peserta yang memiliki foto dan caption terbaik maka akan mendapatkan hadiah 
berupa uang tunai, yaitu juara 1 sebesar 3 juta rupiah, juara 2 sebesar 1,5 juta rupiah, dan juara 3 sebesar 750 ribu rupiah. Hadiah akan di transfer ke rekening para pemenang.

\section{Gambar 11.Show YourSelf Photo Competition}

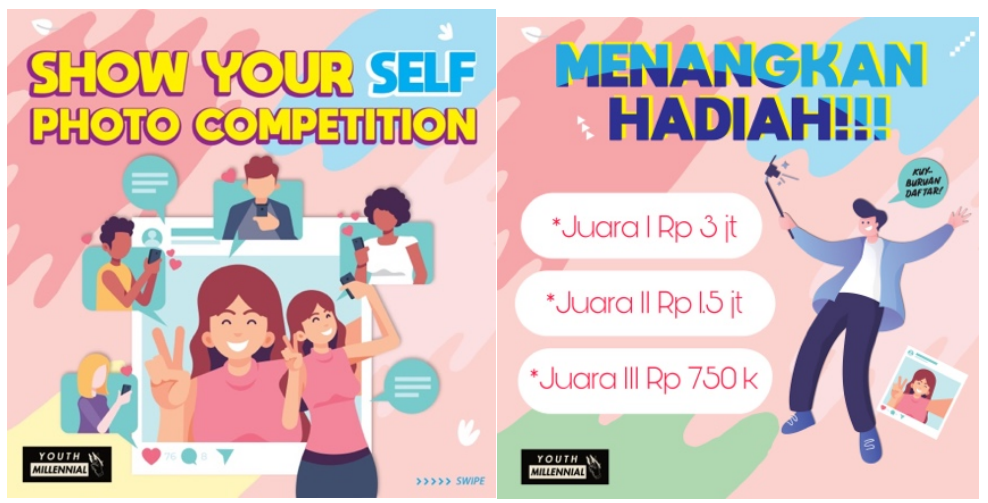

Sumber: Data Olahan Perancang Karya, 2020

3. Social Campaign :Photo Competition \#TanamUntukBumi (22-29 April 2021)

Kampanye ini dilakukan untuk meningkatkan kesadaran orang untuk selalu menjaga kebersihan lingkungan dengan cara memungut sampah yang berserakan di sekitar kita dan mengunggah foto dengan hasil sampah-sampah yang dipungut serta membuat caption dengan hashtag \#PungutUntukBumiYM \#LindungiBumi yang unik, dan wajib tag akun Instagram @youth_Millennial. Kampanye ini akan diselenggarakan pada peringatan Hari Bumi, mulai 22 April sampai dengan 29 April 2021. Pemenang akan diumumkan pada tanggal 30 April. Bagi peserta yang memiliki foto dan caption terbaik maka akan mendapatkan hadiah berupa uang tunai, yaitu juara 1 sebesar 3 juta rupiah, juara 2 sebesar 1,5 juta rupiah, dan juara 3 sebesar 750 ribu rupiah.. Pengumuman pemenang akan diumumkan pada akun Instagram Youth Millennial dan hadiah akan ditransfer ke rekening para pemenang.

Gambar 12. \#PungutUntukBumi photo competition

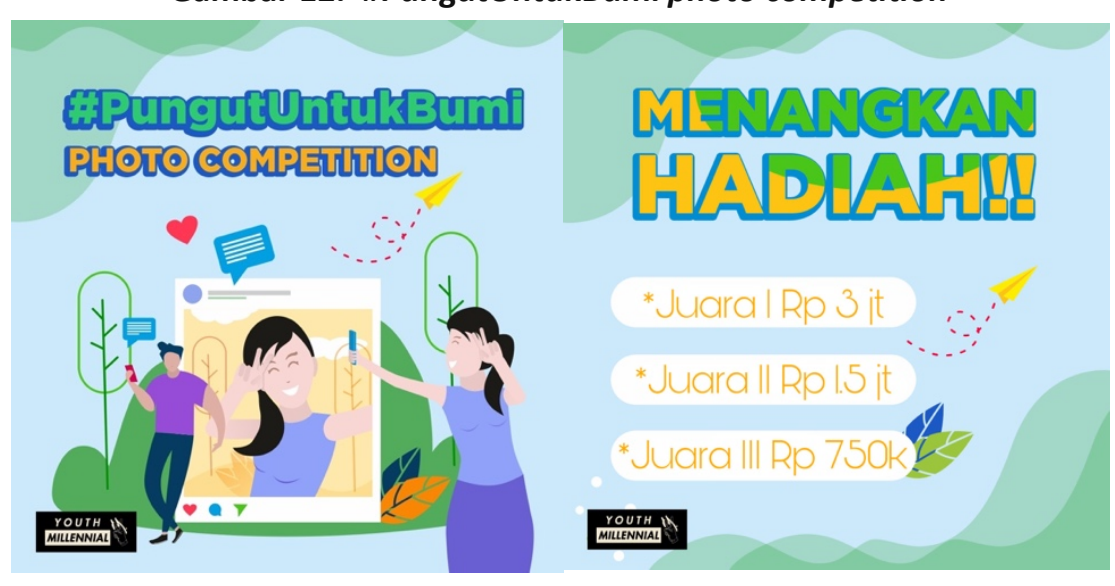

Sumber: Data Olahan Perancang Karya, 2020 


\section{Sales Promotion (Agustus 2020 - Agustus 2021)}

1. Birthday Gifts: Potongan harga sebesar umur pelanggan yang sedang berulang tahun, maksimal 25 tahun untuk semua pembelian produk Youth Millennial. Bagi pelanggan yang ingin menggunakan promo ini wajib mengirimkan bukti bahwa mereka sedang berulang tahun dengan mengirimkan foto kartu identitas penduduk atau kartu mahasiswa. Promo ini berlaku 3 bulan sekali di minggu ke 3 dan ke 4 yaitu pada bulan Agustus 2020, Desember 2020, April 2021 dan Agustus 2021. Promo ini akan diinfokan melalui akun Instagram @youth_millennial.

Gambar 13. Birthday Discount

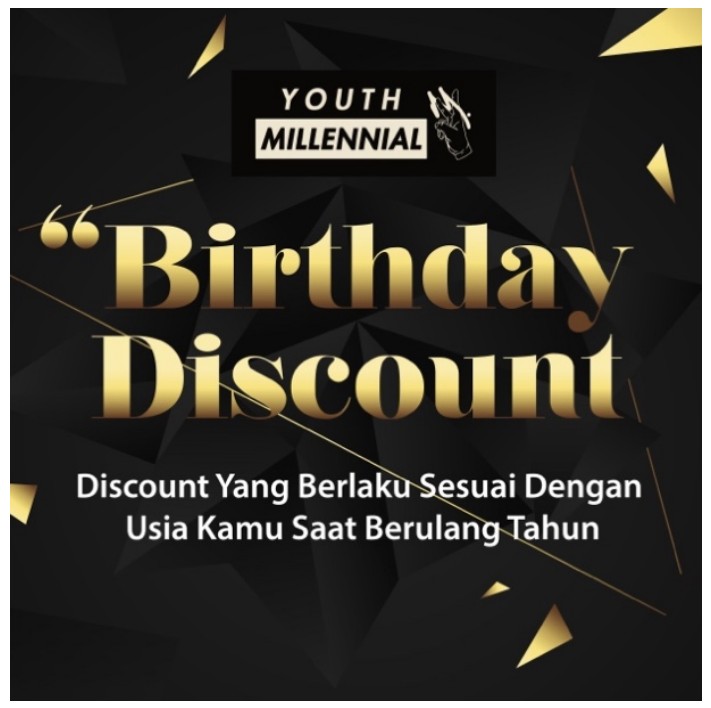

Sumber: Data Olahan Perancang Karya, 2020

2. Buy 3 Get 1: Setiap pembelian 3 produk Youth Millennial akan diberikan gratis 1 produk, berlaku hanya untuk pembelian produk kaus. Promo ini berlaku setiap 2 bulan sekali pada minggu ke 3 dan minggu ke 4 yaitu bulan Oktober 2020, Januari 2021, April 2021 dam Agustus 2020. Promo ini akan diinfokan melalui akun Instagram@youth_millennial.

Gambar 14. Promo Buy 3 Get 1

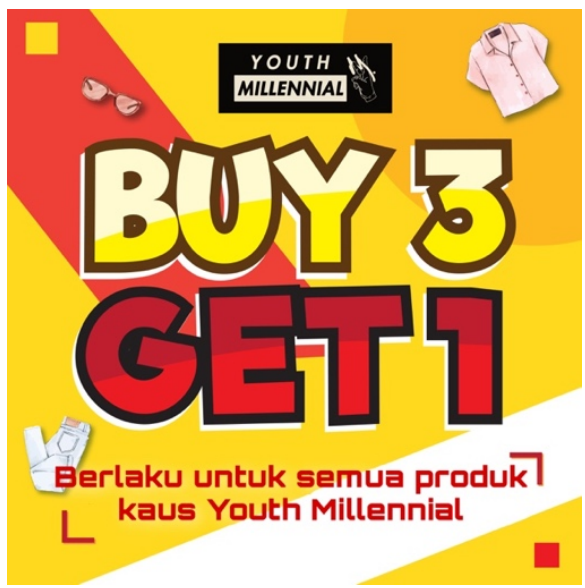

Sumber: Data Olahan Perancang Karya, 2020 
3. Year End Festive Treat: Youth Millennial akan memberikan potongan sebesar $10 \%$ di minggu ke 3 dan 4 pada akhir tahun, tepatnya di bulan desember 2020. Promo ini berlaku bagi semua pembelian produk Youth Millennial.

\section{Gambar 15. Year End Promotion}

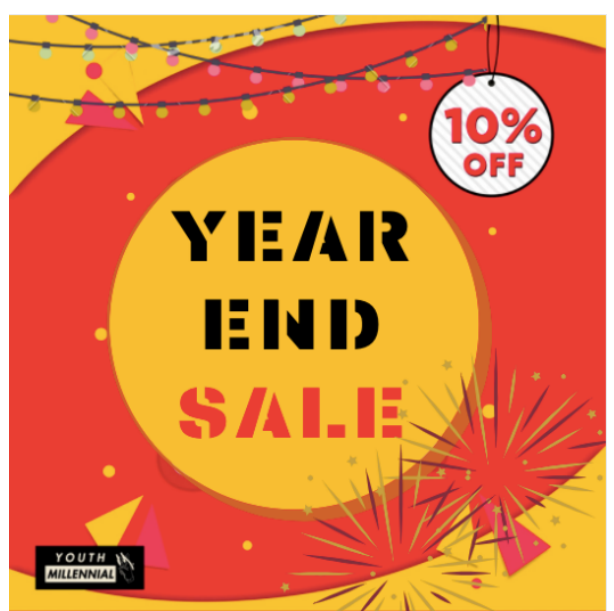

Sumber: Data Olahan Perancang Karya, 2020

4. Idul Fitri Treat: Pada bulan Mei 2021 tepatnya di minggu ke 2, Youth Millennial akan memberikan promo khusus bulan Ramadhan idul fitri sebesar $10 \%$ bagi semua pembelian produk Youth Millennial.

Gambar 16.. Idul Fitr Promotion, dari

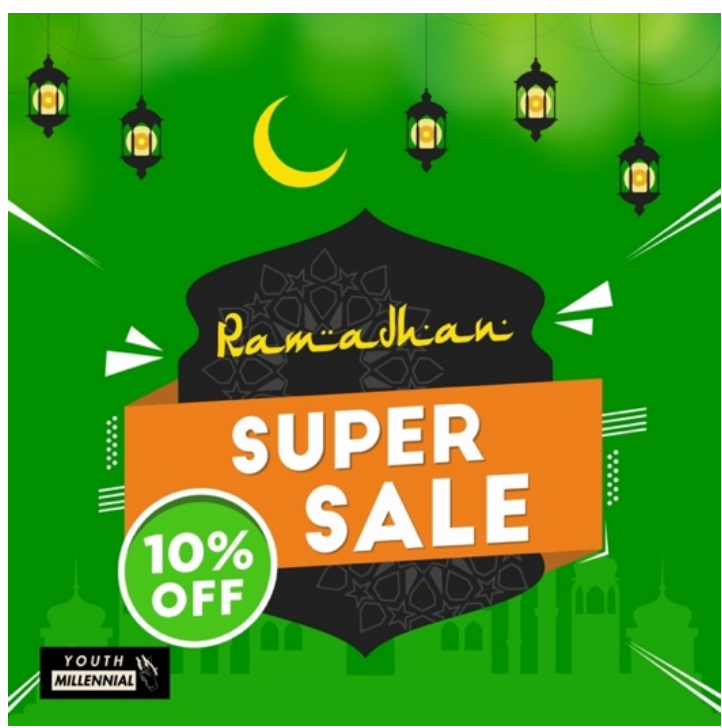

Sumber: Data Olahan Perancang Karya, 2020

5. Valentine Special: Fourteen percent off for Second Item: Pada perayaan hari Valentine Youth Millennial akan memberikan promo khusus untuk setiap pembelian dua produk. Discount sebesar $14 \%$ akan dipotong pada produk kedua yang dibeli customers. 


\section{Gambar 17.Valentine Day Promotion,}

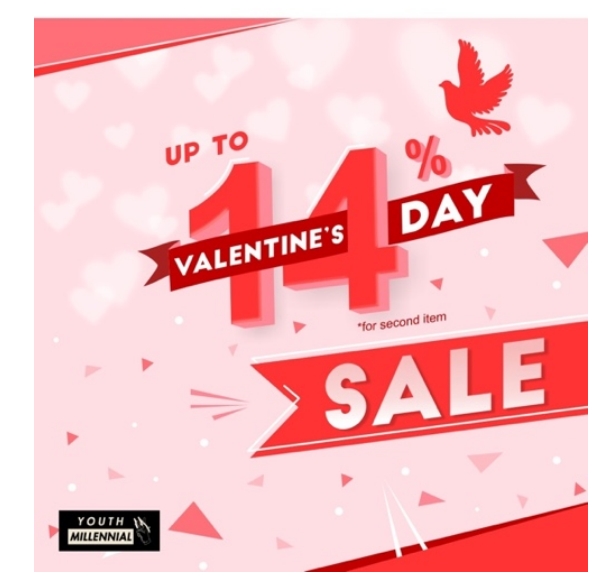

Sumber: Data Olahan Perancang Karya, 2020

6. Potongan 10.000 Ongkos Kirim: Youth Millennial akan memberikan potongan sebesar 10.000 untuk ongkos kirim bagi semua pelanggan yang bertransaksi berbelanja produk Youth Millennial.

\section{Gambar 18. Potongan Ongkir Promotion}

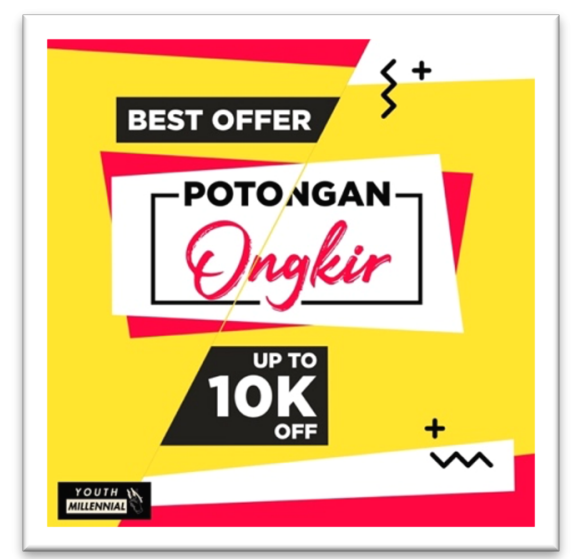

Sumber: Data Olahan Perancang Karya, 2020

\section{Celebrity Endorsement}

Dalam rangka memperluas jangkauan produk, Youth Millennial akan menggunakan jasa influencer yang ada di Instagram. Influencer dipilih berdasarkan kriteria yang sesuai dengan produk Youth Millennial. Sebanyak 24 nfluencer yang ada di Instagram akan dilibatkan, yaitu:

1. @rzkyaltss - 99.7k followers

2. @snathanaell - 23.3k followers

3. @lulalahfah - 1.8m followers

4. @awkarin-5.4m followers

5. @alvinlapian-178k followers

6. hermarzky - 241k followers

7. @diat_zon-577k followers 
8. @safirakaunang - 343k followers

9. @nopriansuryananta-72.1k followers

10. @indragusti16 - 261k followers

11. @jalinahkoda - 183.k followers

12. @jessicasicillia - 194k followers

\section{E-Commerce}

Guna meningkatkan jangkauan dan memudahkan akses penjualan dan pembelian bagi para pelanggan, Youth Millennial akan bekerjasama dengan e-commerce dalam menawarkan semua produk yang dijual. Terdapat dua e-commerce yang akan digunakan, yaitu Shopee dan Tokopedia.

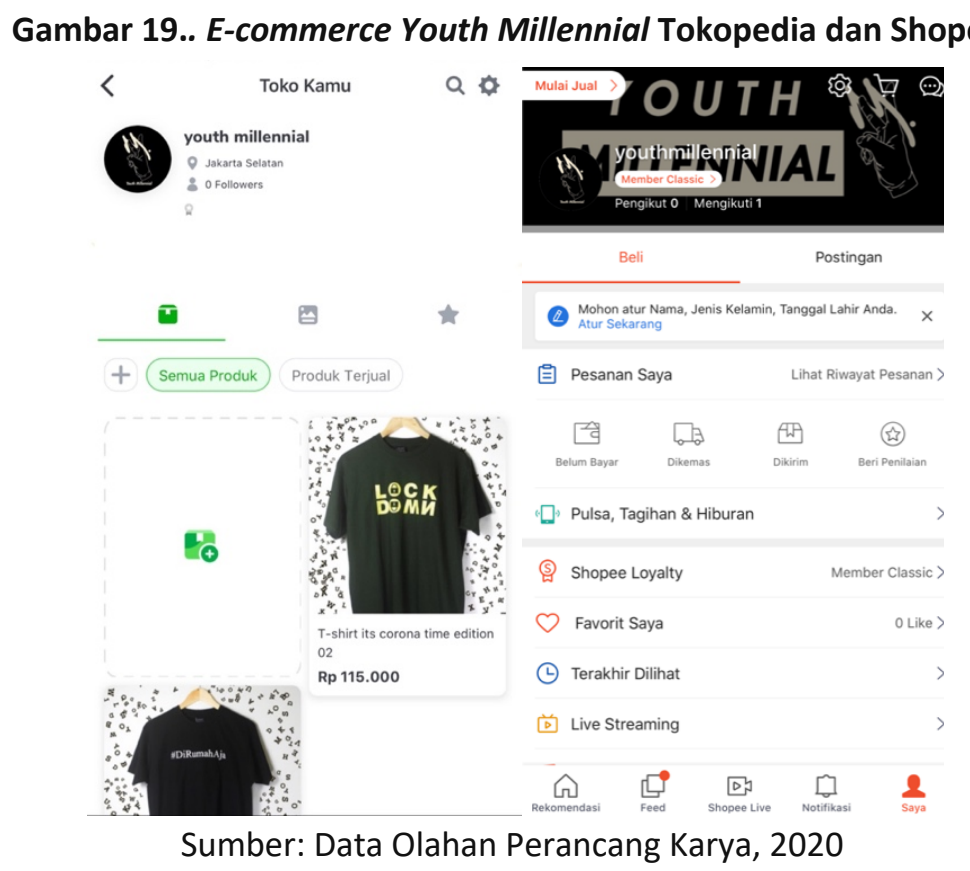

\section{Instagram Ads (Agustus 2020 - Agustus 2021)}

Penempatan iklan pada Instagram Ads direncanakan di bulan Agustus 2020 serta Juli dan Agustus 2021 yang akan fokus untuk membangun awareness audience di Instagram. Jadwal penempatan iklan sebagai berikut:

1. Agustus 2020

Target khalayak: Laki - Laki dan Perempuan, umur 18-30 tahun di Indonesia, durasi promosi: 31 hari

Budget perhari: Rp 20.000,- (Total Rp 620.000,-)

Tujuan: Meningkatkan brand awareness terhadap clothing line Youth Millennial supaya lebih banyak lagi yang sadar mengikuti kampanye yang diadakan oleh Youth Millennial.

Estimasi jangkauan atau reach: $42.000-110.000$

2. Juli dan Agustus 2021 
Target khalayak: Laki - Laki dan Perempuan, umur 18-30 tahun di Indonesia, durasi promosi: 62 hari

Budget perhari: Rp 30.000,- (Total Rp 1.860.000)

Tujuan: Meningkatkan brand awareness terhadap clothing line Youth Millennial khususnya untuk menginformasikanmengenai bazaar yang diikuti oleh clothing line Youth Millennial pada Agustus 2021. Hal ini sekaligus menghasilkan peningkatan sales pada bazaar tersebut.

\section{Personal Selling (Agustus 2021)}

Taktik personal selling ini direncanakan dengan cara mengikuti bazzar di mal - mal tertentu pada bulan Agustus tahun 2021. Rencana mengikuti bazaar ini bisa dilaksanakan jika situasi memungkinkan saat situasi pandemi covid 19 sudah berakhir selama 1 tahun ini. Rencana bazaar yang dilakukan selama 1 bulan penuh, sesuai dengan jadwal kegiatan di 2 mal, yaitu:

1. Mal Pik Avenue, di 2 minggu pertama pada bulan Agustus 2021, ukuran 2x2m.

Harga booth di minggu pertama Rp 3.500.000,-

Harga booth di minggu kedua Rp 6.000.000,-

2. Mal Gandaria City, di minggu ketiga dan keempat pada bulan Agustus 2021, ukuran $3 \times 2 \mathrm{~m}$.

Harga booth Rp 8.500.000,-

Berikut adalah gambaran desain booth pada bazzar beserta desain banner:

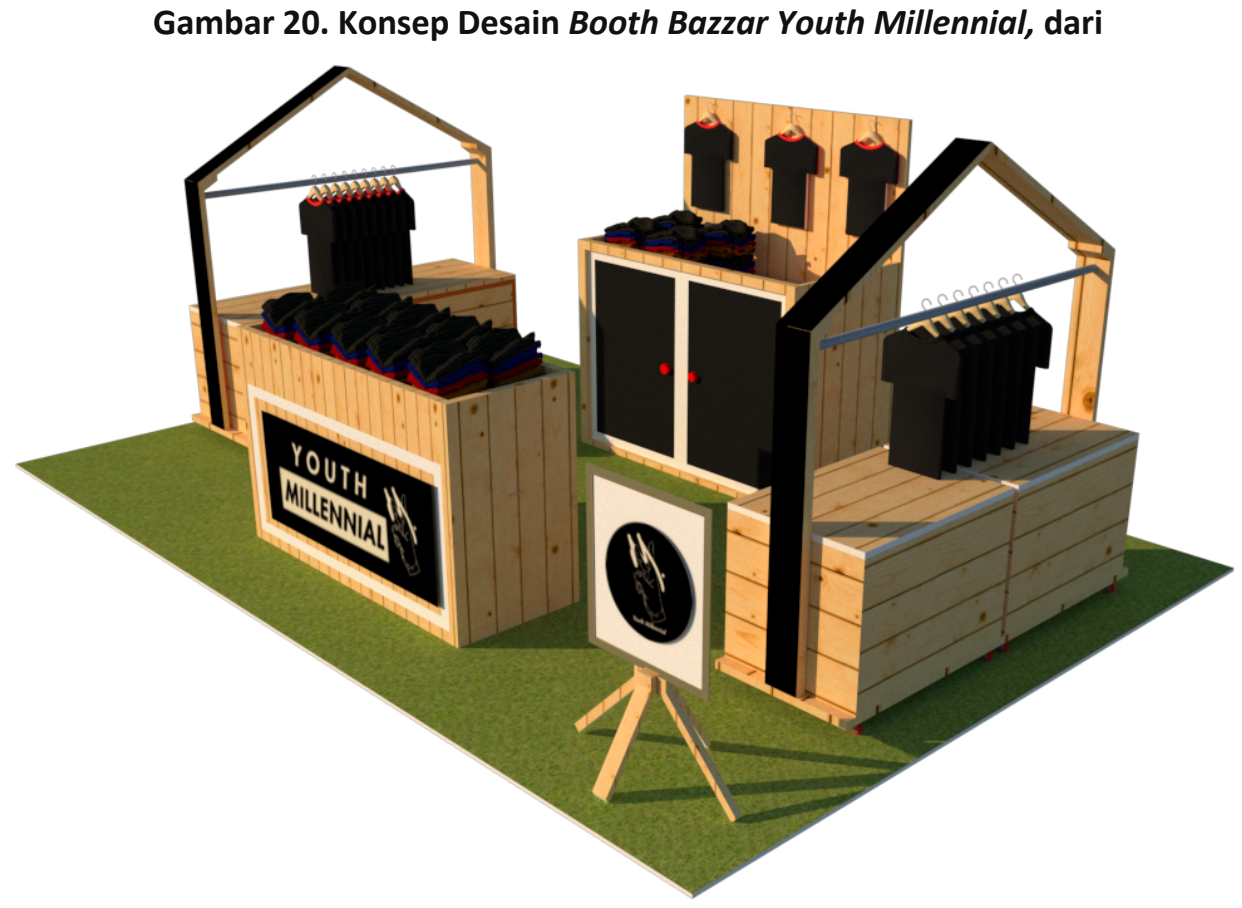

Sumber: Data Olahan Perancang Karya, 2020 
Gambar 21.Konsep Desain Booth Bazzar Youth Millennial,

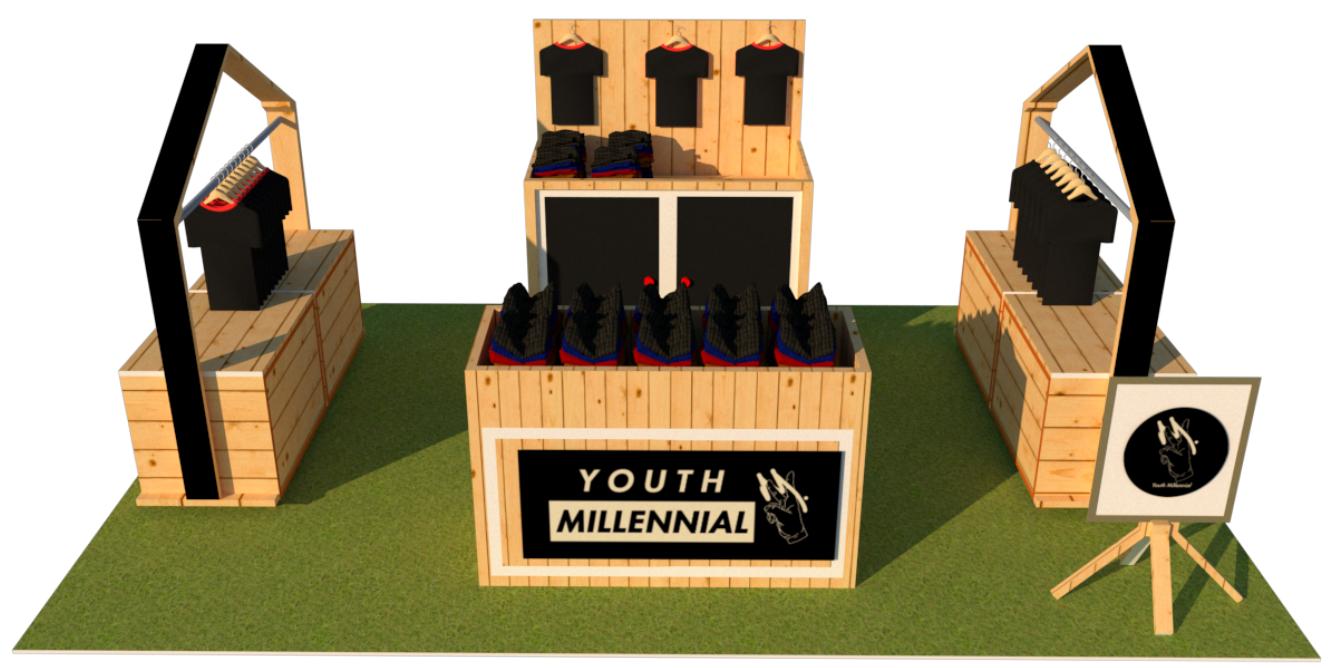

Sumber: Data Olahan Perancang Karya, 2020

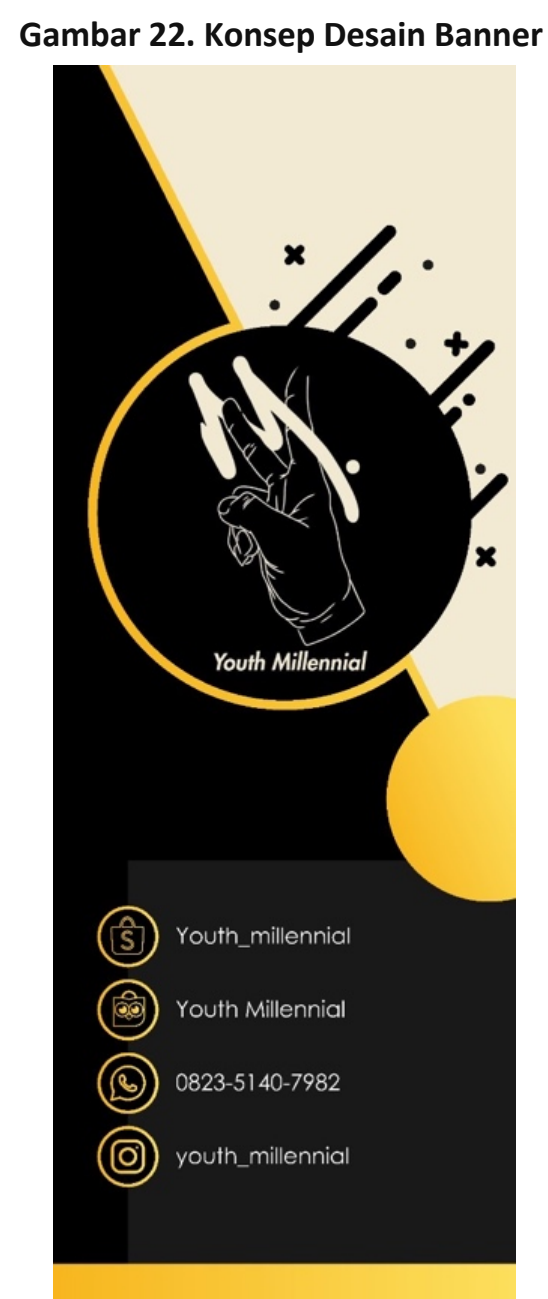

Sumber: Data Olahan Perancang Karya, 2020 
12: STRATEGI KOMUNIKASI PEMASARAN ONLINE SHOP “YOUTH_MILLENNIAL” DALAM MENINGKATKAN KESADARAN MEREK DAN PENJUALAN

\section{Action Timetable}

Gambar 23. Timetable Promosi

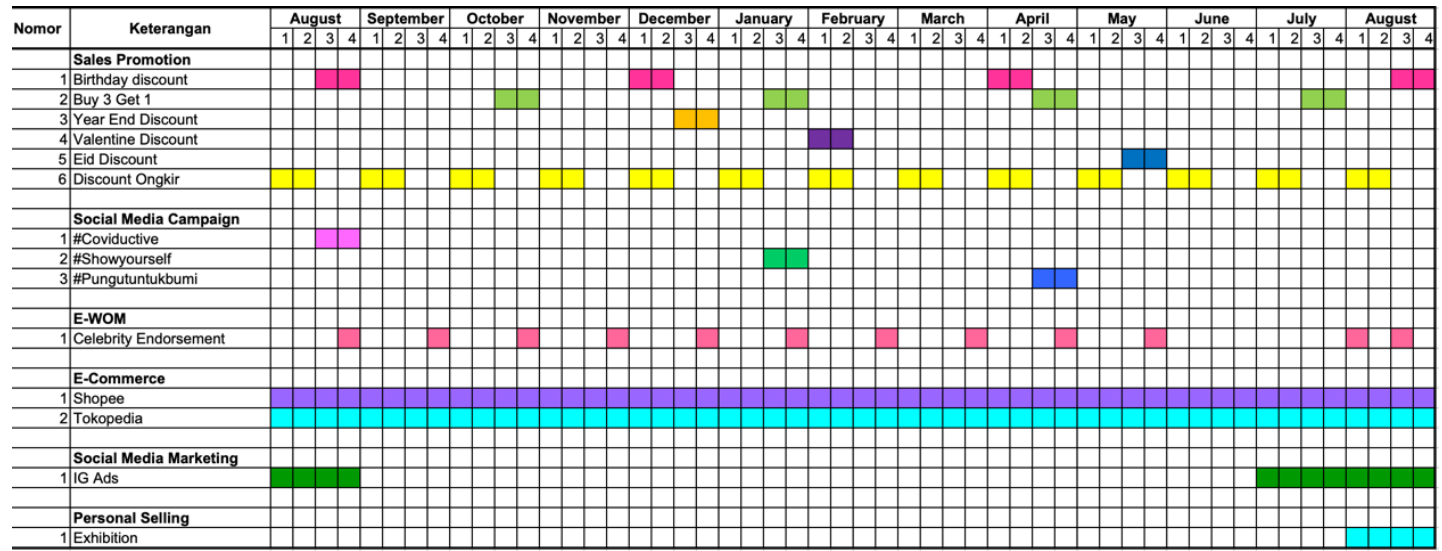

Sumber: Data Olahan Perancang Karya, 2020

\section{Control}

Seteleh melakukan tahap- tahap untuk membuat strategi komunikasi pemasaran pada online shop Youth Millennial, tahap terakhir adalah melakukan kontrol. Tahap ini perlu dilakukan untuk melakukan evaluasi apakah perencanaan yang dibuat sudah terlaksana secara efektif. Tahap kontrol dilakukan dengan cara sebagai berikut:

1. Memantau jumlah followers pada online shop Instagram Youth Millennial untuk melihat tingkat kenaikan brand awareness.

2. Evaluasi setiap bulan terhadap laporan penjualan untuk melihat apakah terdapat peningkatan penjualan selama periode promosi berlangsung.

3. Menghitung jumlah orang yang telah ikut serta dalam kampanye melalui hashtag kampanye masing - masing.

4. Evaluasi hasil penjualan melalui e-commerce di Tokopedia dan Shopee serta melihat review yang diberikan oleh pelanggan yang telah melakukan pembelian.

5. Memonitor jumlah engagement yang dihasilkan pada penempatan iklan di Instagram Ads.

6. Melihat jumlah kunjungan atau visit profile Instagram online shop Youth Millennial untuk melihat tingkat brand awareness yang dihasilkan.

\section{Budgeting}

Tabel 4. Budget Promosi

\begin{tabular}{|c|c|c|c|c|}
\hline No & Keterangan & Kuantiti & Harga & Total \\
\hline & Kampanye Sosial & & & \\
\hline 1 & Booth PIK Avenue Week 1 & 1 & $\operatorname{Rp} \quad 3.500 .000,00$ & $\mathrm{Rp} \quad 3.500 .000,00$ \\
\hline 2 & Booth PIK avenue Week 2 & 1 & Rp $\quad 6.000 .000,00$ & Rp $\quad 6.000 .000,00$ \\
\hline 3 & Mal Gandaria City Week 3-4 & 1 & $\mathrm{Rp} \quad 8.500 .000,00$ & $\mathrm{Rp} \quad 8.500 .000,00$ \\
\hline 4 & X-Banner & 1 & $\operatorname{Rp} 65.000,00$ & $\operatorname{Rp} 65.000,00$ \\
\hline 5 & Promo Buy 3 get 1 & 0 & & $\mathrm{Rp}$ \\
\hline \multirow[t]{2}{*}{6} & Gift & & & $\mathrm{Rp}$ \\
\hline & Item 1 & 3 & $\mathrm{Rp} \quad 3.000 .000,00$ & $\mathrm{Rp} \quad 9.000 .000,00$ \\
\hline
\end{tabular}




\begin{tabular}{|c|c|c|c|c|c|}
\hline & Item 2 & 3 & $\mathrm{Rp}$ & $1.500 .000,00$ & Rp $4.500 .000,00$ \\
\hline & Item 3 & 3 & $\mathrm{Rp}$ & $750.000,00$ & Rp $2.250 .000,00$ \\
\hline \multirow[t]{4}{*}{7} & Iklan Instagram (Per Hari) & & & & $\mathrm{Rp}$ \\
\hline & Agustus 2020 & 31 & $\mathrm{Rp}$ & $20.000,00$ & $620.000,00$ \\
\hline & Juli dan Agustus 2021 & 62 & $\mathrm{Rp}$ & $20.000,00$ & Rp $1.240 .000,00$ \\
\hline & Sales Promotion & & & & \\
\hline 8 & Valentine Discount & 150 & $\mathrm{Rp}$ & $20.000,00$ & Rp $3.000 .000,00$ \\
\hline 9 & Subsidi gratis ongkos kirim & 250 & $\mathrm{Rp}$ & $10.000,00$ & Rp $2.500 .000,00$ \\
\hline 10 & Eid Discount & 150 & $\mathrm{Rp}$ & $15.000,00$ & Rp $\quad 2.250 .000,00$ \\
\hline \multirow[t]{2}{*}{11} & Year end Discount & 150 & $\mathrm{Rp}$ & $15.000,00$ & $\operatorname{Rp} \quad 2.250 .000,00$ \\
\hline & Public Relations (Endorsen & & & & \\
\hline 10 & @rzkyaltss & 1 & $\mathrm{Rp}$ & $350.000,00$ & $350.000,00$ \\
\hline 11 & @snathanaell & 1 & $\mathrm{Rp}$ & $250.000,00$ & $250.000,00$ \\
\hline 12 & @lulalahfah & 1 & $\mathrm{Rp}$ & $2.000 .000,00$ & Rp $2.000 .000,00$ \\
\hline 13 & @awkarin & 1 & & $10.000 .000,00$ & Rp $10.000 .000,00$ \\
\hline 14 & @alvinlapian & 1 & $\mathrm{Rp}$ & $200.000,00$ & $200.000,00$ \\
\hline 15 & @hermarzky & 1 & $\mathrm{Rp}$ & $200.000,00$ & $200.000,00$ \\
\hline 16 & @diat_zon & 1 & $\mathrm{Rp}$ & $300.000,00$ & $300.000,00$ \\
\hline 17 & @safirakaunang & 1 & $\mathrm{Rp}$ & $250.000,00$ & $250.000,00$ \\
\hline 18 & @nopriansuryanata & 1 & $\mathrm{Rp}$ & $170.000,00$ & $170.000,00$ \\
\hline 19 & @indragusti16 & 1 & $\mathrm{Rp}$ & $170.000,00$ & $170.000,00$ \\
\hline 20 & @jessicasicillia & 1 & $\mathrm{Rp}$ & $300.000,00$ & $300.000,00$ \\
\hline 21 & @jalinahkoda & 1 & $\mathrm{Rp} 3$ & $20.000,00$ & $\operatorname{Rp} 320.000,00$ \\
\hline Total & & & & & $\operatorname{Rp} 60.185 .000,00$ \\
\hline
\end{tabular}

Sumber: Data Olahan Perancang Karya, 2020

Tabel 5. Budget Produksi

\begin{tabular}{llllrlr} 
No & Keterangan & Kuantiti & \multicolumn{2}{l}{ Harga } & \multicolumn{2}{l}{ Total } \\
\hline 1 & Jasa Sablon & 500 & $\mathrm{Rp}$ & $20.000,00$ & $\mathrm{Rp}$ & $10.000 .000,00$ \\
\hline 2 & Bahan Kaus & 500 & $\mathrm{Rp}$ & $41.000,00$ & $\mathrm{Rp}$ & $20.500 .000,00$ \\
\hline 3 & Jasa-Bahan Hoodie & 250 & $\mathrm{Rp}$ & $150.000,00$ & $\mathrm{Rp}$ & $37.500 .000,00$ \\
\hline 4 & Jasa-Bahan Kemeja & 244 & $\mathrm{Rp}$ & $150.000,00$ & $\mathrm{Rp}$ & $36.600 .000,00$ \\
\hline 5 & Hang Tag 520 pcs & 994 & $\mathrm{Rp}$ & 300,00 & $\mathrm{Rp}$ & $298.200,00$ \\
\hline 6 & Ongkir Pabrik & 1 & $\mathrm{Rp}$ & $350.000,00$ & $\mathrm{Rp}$ & $350.000,00$ \\
\hline 7 & Label Brand & 1 & $\mathrm{Rp}$ & $200.000,00$ & $\mathrm{Rp}$ & $200.000,00$ \\
\hline 8 & Ongkir Distributor & 1 & $\mathrm{Rp}$ & $350.000,00$ & $\mathrm{Rp}$ & $350.000,00$ \\
\hline 9 & Packaging Amplop & 520 & $\mathrm{Rp}$ & $1.000,00$ & $\mathrm{Rp}$ & $520.000,00$ \\
\hline 10 & Packaging Plastik & 520 & $\mathrm{Rp}$ & 200,00 & $\mathrm{Rp}$ & $104.000,00$ \\
\hline 11 & Budget Porter & 1 & $\mathrm{Rp}$ & $1.000 .000,00$ & $\mathrm{Rp}$ & $1.000 .000,00$ \\
\hline Total & & & & & $\mathrm{Rp}$ & $107.422 .200,00$
\end{tabular}

Sumber: Data Olahan Perancang Karya, 2020 
Tabel 6. Sales Forecast

\begin{tabular}{|c|c|c|c|c|c|c|}
\hline No & Nama Barang & Kuantiti & Har & & Tota & \\
\hline 1 & Kemeja & 500 & $\mathrm{Rp}$ & $125.000,00$ & $\mathrm{Rp}$ & $62.500 .000,00$ \\
\hline 2 & Hoodie & 250 & $\mathrm{Rp}$ & $230.000,00$ & $\mathrm{Rp}$ & $57.500 .000,00$ \\
\hline 3 & Kemeja & 244 & $\mathrm{Rp}$ & $275.000,00$ & $\mathrm{Rp}$ & $67.100 .000,00$ \\
\hline
\end{tabular}

Sumber: Data Olahan Perancang Karya, 2020

\section{SIMPULAN}

Dalam rangka meningkatkan awareness dan sales pada brand Youth Millennial dan meningkatkan loyalitas konsumen, maka dibutuhkan beberapa strategi komunikasi pemasaran yang sesuai dengan target market Youth Millennial.

Perencana telah melakukan strategi pemasaran berdasarkan SOSTAC. Adapun strategi yang diputuskan adalah dengan melakukan bazar, sales promotion, endorsement, kompetisi foto, dan personal selling. Rekomendasi untuk brand Youth Millennial adalah agar secara konsisten melakukan promosi yang dapat memikat ketertarikan audience khususnya pada sosial media, dan diharapkan dapat selalu mengembangkan brand Youth Millennial dari segi design produk dan kualitasnya yang sesuai dengan ketertarikan audiens agar terciptanya brand loyalty

\section{DAFTAR PUSTAKA}

Anna, L.K. (2018, Agustus 30). Pekan Raya Indonesia Hadirkan Clothing Distro. Diperoleh pada September 30, 2019, dari website Kompas: https://lifestyle.kompas.com/read/2018/08/30/093800220/pekan-raya-indonesiahadirkan-clothing-distro-80-merek-lokal

Anwar, M. (2019). Dasar-dasar Manajemen Keuangan Perusahaan. Jakarta: Kencana.

Badan Ekonomi Kreatif [BEKRAF]. (n.d). (2018, June). Bangkitnya Label Lokal: Wadah Kreativitas Anak Bangsa. Diperoleh pada Oktober 3, 2019, dari https://www.bekraf.go.id/downloadable/pdf_file/180799- retas-vol-7\%20\%20juni2018-bangkitnya-label-lokal.pdf

Chaffey, D \& Smith, P.R. (2013). Emarketing Excellence: Planning and Optimizing Your Digital Marketing. New York: Routledge

Chaffey, D \& Smith, P.R. (2017). Digital Marketing Excellence: Planning And Optimizing Your Online Marketing . New York: Routledge

Firmanzah. (Eds). (2011). Mengelola Partai Politik: Komunikasi dan positioning Ideologi Politik di Era Demokrasi. Jakarta: Yayasan Pustaka Obor Indonesia. 
Kembuan, P.C., Mananeke, L., \& Soegoto, A.S. (2014). Analisis Segmentasi, Targeting, dan Positioning Pembiayaan Mobil Pada PT. Adira Dinamika Multifinance TBK Cabang Manado. Jurnal EMBA, 2 (3), 854-856. ISSN: $\quad$ 2303-1174.

Mahi, A.K., \& Trigunarso, S.I. (2017). Perencanaan Pembangunan Daerah Teori dan Aplikasi. Jakarta: Kencana.

Morrisan. (2010). Periklanan Komunikasi Pemasaran Terpadu. Jakarta: Prenadamedia Group.

Pertiwi, W. K. (2019, Juli 20)."Hampir Setengah Penduduk Bumi Sudah Melek Media Sosial.” Diperoleh pada September 25, 2019, darihttps://tekno.kompas.com/read/2019/07/20/16370017/hampir- setengahpenduduk-bumi-sudah-melek-media-sosial

Prasetyo, B.D., Febriani, N.S., Asmara, W.W., Tamitiadini, D.D., Destrity, N.A., Avina, D.A.A., \& Illahi, A.K. (2018). Komunikasi Pemasaran Terpadu: Pendekatan Tradisional Hingga Era Media Baru. Malang: UB Press.

Primyastanto, M. (2016). Evapro (Evaluasi Proyek) Teori dan Aplikasi Pada Usaha Pembesaran Ikan Sidat (Anguilla sp). Malang: UB Press.

Putera, A. D. (2018, September 7). “Jumlah Pembeli ‘online’ Indonesia capai 11,9 persen dari Popuasi". Diperoleh pada September 25, 2019, dari web site Kompas:

Kompas.com. (2018). Jumlah pembeli online Indonesia capai 119 persen dari populasi. https://ekonomi.kompas.com/read/2018/09/07/164100326/jumlah- pembelionline-indonesia-capai-119-persen-dari-populasi

Rangkuti, F. (2011). Dongkrak Penjualan Melalui Strategy \& Competitive Positioning. Jakarta: PT Gramedia Pustaka Utama.

Ries,E. 2018. The Lean Startup:Ketika Inovasi Tanpa Henti Menciptakan Kesuksesan Bisnis Secara Radikal. Diterjemahkan oleh: Indardini. Yogyakarta: Bentang.

Rini, A.S. (2019, Mei 06). Permintaan Pakaian Jadi Naik. Diperoleh pada September 28, 2019 dari web site Kemenperin: https://kemenperin.go.id/artikel/20640/PermintaanPakaian-Jadi- \%20Naik

Smith, P. R \& Zook, Z (Eds). (2011). Marketing Communications: Offline and Online Integration, Engagement, and Analystics. London: Kogan Page Limit.

Sokowski, D,W. (2015). Mastering Project Management Integration and Scope. United State: Paul Boger

Supriatna, Y., Adiyanto, Y.,Sunaryo, D. (2019). Induksi Manajemen Pemasaran. Pasuruan: CV Qiara Media Partner.

Syahid. (2018, Agustus 10). "Pemasaran: Generasi Millenial Ingin Bisnis Clothing Line? Simak Caranya Berikut Ini." Diperoleh pada September 29, 2019 dari https://elshinta.com/news/152695/2018/08/10/generasi-millenial-ingin\%20\%20bisnis-clothing-line-simak-caranya-berikut-ini

We Are Social. (2020)."Digital 2020 Indonesia." diperoleh dari DataReportal :https://datareportal.com/reports/digital-2020-indonesia

Wijayanti, T. (2017). Marketing Plan! Dalam Bisnis Third Edition. Jakarta: PT Elex Media Komputindo. 